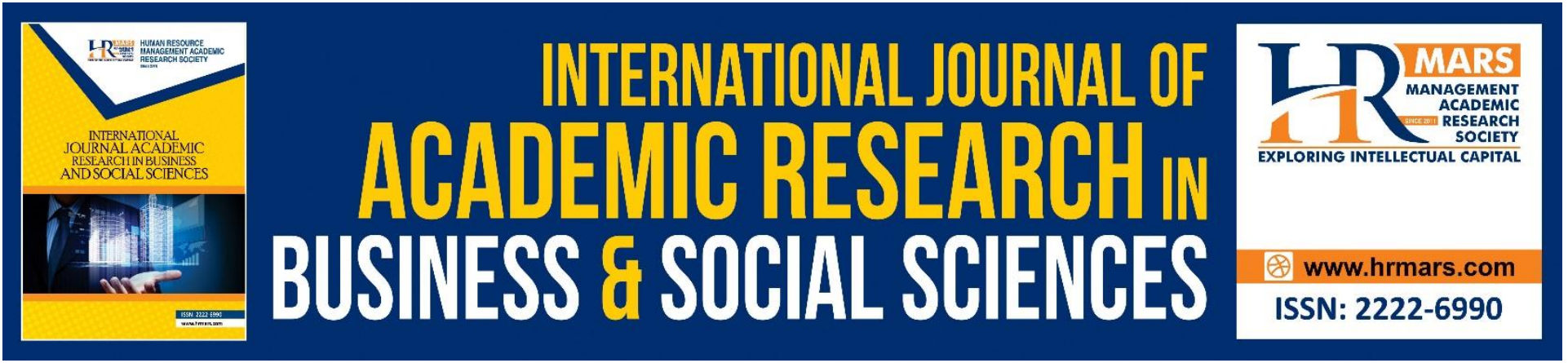

\title{
Exploring Work from Home Amidst Post-Covid
}

Noor Hanim Rahmat, Sharifah Amani Syed Abdul Rahman, D Rohayu Mohd Yunos, Nadzrah Sa'adan, Nurul Hijah Jasman, Syed Salleh Syed Abdul Rahman

To Link this Article: http://dx.doi.org/10.6007/IJARBSS/v12-i1/12026

DOI:10.6007/IJARBSS/v12-i1/12026

Received: 12 November 2021, Revised: 16 December 2021, Accepted: 26 December 2021

Published Online: 22 January 2022

In-Text Citation: (Rahmat et al., 2022)

To Cite this Article: Rahmat, N. H., Rahman, S. A. S. A., Yunos, D. R. M., Sa'adan, N., Jasman, N. H., \& Rahman, S. S. S. A. (2022). Exploring Work from Home Amidst Post-Covid. International Journal of Academic Research in Business and Social Sciences, 12(1), 1107-1120.

Copyright: (c) 2022 The Author(s)

Published by Human Resource Management Academic Research Society (www.hrmars.com)

This article is published under the Creative Commons Attribution (CC BY 4.0) license. Anyone may reproduce, distribute, translate and create derivative works of this article (for both commercial and non0-commercial purposes), subject to full attribution to the original publication and authors. The full terms of this license may be seen at: http://creativecommons.org/licences/by/4.0/legalcode

Vol. 12, No. 1, 2022, Pg. $1107-1120$

Full Terms \& Conditions of access and use can be found at http://hrmars.com/index.php/pages/detail/publication-ethics 


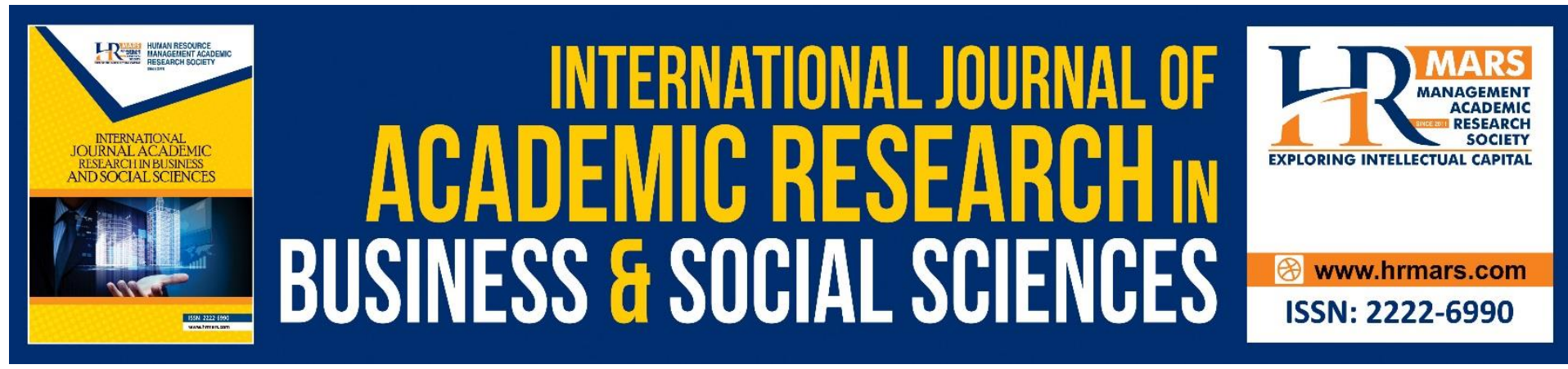

\title{
Exploring Work from Home Amidst Post-Covid
}

\author{
Noor Hanim Rahmat ${ }^{1}$, Sharifah Amani Syed Abdul Rahman², D \\ Rohayu Mohd Yunos ${ }^{3}$, Nadzrah Sa'adan ${ }^{4}$, Nurul Hijah \\ Jasman $^{5}$, Syed Salleh Syed Abdul Rahman ${ }^{6}$ \\ 1,2,3,4,5Akademi Pengajian Bahasa, Universiti Teknologi MARA Cawangan Johor, \\ Kampus Pasir Gudang, Johor Darul Takzim, Malaysia, ${ }^{6}$ Novartis Pharmaceutical Corporation, \\ Selangor, Malaysia \\ Email: noorh763@uitm.edu.my,shari348@uitm.edu.my,droha932@uitm.edu.my, \\ nadzr210@uitm.edu.my,nurulhijah@uitm.edu.my, syedsalleh86@gmail.com
}

\section{Abstract}

Time has passed since the World Health Organization declared Covid-19 a pandemic. Hundreds of millions of people have lived in and out of lockdowns. Interestingly, the pandemic has opened our eyes to the possibility of making work from home a norm. . There are two opposing views when it comes to working from home. One view says that people will get nothing done, and the other view believes workers will be happier and more productive working from home. Therefore, this pilot study attempts to investigate both sides of the coin for issues relating to working from home. 44 participants responded to this quantitative study. The instrument used is a questionnaire. It looks at how working from home influence work-life balance, work fulfilment and also work performance of workers. In ensuring the reliability of the instrument, the reliability analysis has been conducted on the instrument comprising of 34 items with four sections; Section A: Demographic Data, Section B: Work Fulfilment, Section C: Work-life Balance and Section D: Work Performance. Findings revealed interesting implications for employers to consider work from home as a new norm.

Keywords: Working From Home, Work-Life Balance, Work Fulfilment, Work Performance

\section{Introduction}

Background of Study

Flashback to 2020, to contain the spread of Covid-19, the Malaysian government introduced the Movement Control Order (MCO) on 18 March 2020. The order included the closure of public and private premises, halting most economic activities in the country except for several essential services. Consequently, many workers were made to work from home. Although the MCO was subsequently replaced by a recovery phase in which workers could return to work, working from home might persist for some workers as vaccines are still being developed.

And although the government has allowed 100 percent of the private sector workforce to return to offices, many companies, especially multinational corporations, have embraced the full work-from-home (WFH) system or a hybrid of office and home arrangement for their employees, with all the mechanisms and settings already secured. 
Returning to current 2022, work from home has become a norm and many industries found that they preferred this concept. Working from home used to be a privilege to some and is only offered by a handful of companies around the world. Work from home, or better known with its acronym WFH, is still a relatively new concept in Malaysia. But ever since the Covid19 pandemic took over the world by surprise in the early 2020, many companies have been forced to move from conventional operating practises to complete or partial WFH

But what exactly is WFH? Work from home (or Working from Home) is a modern work method allowed by the internet and accessibility that allows individuals to work regardless of their physical location. Working from home, also known as working remotely or telecommuting, refers to an employee who works from a remote location, typically their home. The WFH concept was initially mentioned in the article "Traffic reduction by telecommuting: A status review and selected bibliography", "known as "telecommuting" or "telework" (Vyas \& Butakhieo, 2020). WFH has been defined in various terms over the four decades, namely remote work, flexible workplace, telework, telecommuting, e-working. These terms refer to the ability of employees to work in flexible workplaces, especially at home, by using technology to execute work duties (Gajendran and Harrison, 2007; Grant et al., 2019).

\section{Statement of Problem}

Two years have passed since the World Health Organization declared Covid-19 a pandemic. Hundreds of millions of people have lived through lockdowns. Many have made the abrupt shift to working from home. While this may be an inconvenience, not having to go to the office can offer people surprising opportunities to develop a better work-life balance. They can tailor their own working day. In fact, as they do not have to commute, working from home also may boost their productivity. In fact, the study by Rupietta \& Beckmann (2016) also concluded that working from home has a statistically significant positive effect on work effort. Working from home can free people from several constraints but it can still be tough if not managed properly. First of all, there must be a balance between work life and also home chores. This means that even though people may work from the comforts of their living room, the time and space for their jobs and housework must be clearly defined. Furthermore, the environment must be conducive. Sometimes a noisy background may hinder work or meeting from being carried out effectively. In addition, the loss of normal work structure and continuity can be disorienting and exhausting for some people. In fact, working away from your co-workers, with only remote online meetings, risks emotional disconnection and apathy which may lead to procrastination. Xiao et al (2021) findings also showed significant impact on workers' physical and mental well-being during COVID-19 pandemic. Thus, people working from home sometimes struggle with productivity.

There are two opposing views when it comes to working from home. One view usually says that people will get nothing done, and the other view believes workers will be happier and more productive. Therefore, this study attempts to investigate both sides of the coin for issues relating to working from home.

\section{Objective and Research Question}

The objective of this study is to investigate the perception of employees about working from home. This study answers the following research questions;

(a) How does work from home influence work fulfilment of employees? 
(b) How does work from home influence work-life balance of employees?

(c) How does work from home influence work performance of employees?

(d) What is the most fulfilled factor in work from home?

\section{Literature Review}

Downside of Work from Home

While WFH is generally preferred by many workers, and was the most popular opinion, it does express the majority view. as it can also can lead to more challenges if not handled properly. In a 2017 study conducted by the United Nations on 15 countries, including the United States, United Kingdom, Japan, India, Spain and Sweden, 41 per cent of employees who worked from home considered themselves highly stressed, compared to only 25 per cent who worked onsite, contradicting the common belief that WFH is easier (Murugesan, 2020). One such survey done by Vyas and Butakhieo (2020) on the impact of working during Covid-19 in Hong Kong, has found that among the downside of WFH is the dissatisfaction with organisational facilities, such as no or restricted access to services including office records (FastLane, 2020). This could indicate a lack of preparedness for this situation, but given that this is a modern job procedure, both employers and workers would be constrained in their preparedness. As a consequence, employees are likely to be inconsistent or productivity are delayed in terms of output. They are also less flexible which may result in intolerance among others. Employers may have been making efforts, but there has been a lack of consistency, with just $32 \%$ of employers investing in emerging ways of communication technology, and far less in other sectors (FastLane, 2020).

In Malaysia, gaps in digital infrastructure and the nature of work across the country mean that this working arrangement is unlikely to be the "new normal" for most workers in Malaysia. The role of technology in the world of work has, without a doubt, become particularly important. Digitalisation and automation are some of the ways for businesses to be more productive, and are even necessary to survive during Covid-19. However, there are potentially dire implications for workers. Jobs most affected by Covid-19, either because they cannot be home-based or face higher infection risks, also happen to be jobs that can be automated. In the case of Malaysia, most employment is concentrated in these jobs, putting many workers at risk of being displaced (Tumin, 2020).

Work from Home: A Blessing

Work from Home (WFH) has benefits for both employers and employees. The advantages include and are not limited to the following: reducing commuting time, avoiding office politics, using less office space, increased motivation, improved gender diversity (for women and their careers), a healthier workforce with less absenteeism and turnover, higher talent retention, job satisfaction, and better productivity (Mello 2007; Robertson, Maynard, and McDevitt 2003). In fact, Purwanto et al. (2020) also mentioned in his research that WFH saves travel time and money as the employees do not have to commute to work. Moreover, Purwanto et al. (2020) also argued that WFH could support employees in terms of flexible time to complete their work and save money for commuting to work. It also allows colleagues to broaden their networking, get to know other team members from other affiliations and to feel more comfortable to share content like humourous emojis or videos that they necessarily would not be sharing in the past before. It could be because before COVID-19, they may not have met for coffee or any other social activities because they feared it would be unprofessional. Other studies on WFH have also shown that productivity increases, and work 
is completed faster than before. Thus, it is believed that job satisfaction increases as workers are able to work according to their preferred time and also be with their family.

Cognitive Evaluation Theory and Its Impact on Satisfaction at Work

According to Deci and Ryan (2000), The Cognitive Evaluation Theory (CET) is described in terms of how environmental factors can influence the intrinsic motivation. The two variables involved are competence and autonomy. In the context of work environment, CET proposes that the environment and social context can make a worker feel competent. This feeling of competence has a positive effect on his/her intrinsic motivation. Next, intrinsic motivation is positively impacted when workers feel competent and autonomous. So when workers engage in activities for internal rather than external reasons, there will be positive effects on their intrinsic motivation.

\section{Past Studies}

Despite many people's general support for WFH activities, it is clear that there are significant problems that need to be addressed. Purwanto et. al (2020) in his study on the impact of Work From Home (WFH) on Indonesian Teachers Performance During the Covid-19 Pandemic found both advantages and disadvantages to the WFH program to the teachers involved. Respondents were 6 teachers at an elementary school in Tangerang and are given the initials R1, R2, R3, R4, R5 and R6 for confidentiality purposes. Semi-structured interviews were conducted and a list of questions compiled for interviews was developed based on the related literature. The study found that as much as WFH promises a lot of advantages, it also can cause lack of motivation due to electricity and internet problems as well as privacy issues such as the breach of data security. The lack of motivation comes from the fact that the working environment is not the same as working from office, ranging from distractions from sources such as social media and other entertainments. The teachers also had to bear the possibility of electricity and internet usage on their own due to continuous use when WFH.

Another study by Suresh (2020) looked at the most ignored aspect of WFH scenario which are the physical well-being and postural challenges.. An online survey was conducted through the use of Google forms where a total of 326 respondents participated across the world (majority being from India). The study has pointed out that despite having a proper study table and chair, respondents complained of neck and back pain. While the participants were aware of proper working conditions, they were oblivious of the standard ergonomic working height ratio. Hence, the major impact of this pandemic from an ergonomic aspect, has been the realization of the need of a proper workspace at home.

Working from home can affect the employees in positive ways. The study by Susilo (2020) was done to investigate the effects of work-from-home on job performance. The study proposed that work environment, job satisfaction and work motivation are related. 330 employees responded to a questionnaire. Findings revealed that working from home, employees experienced greater enjoyment, satisfaction and motivation thus enhancing job performance.

The study by Rupietta \& Beckmann (2016) investigates the perception of employees about work from home. 5311 samples were taken from employees who worked in industries, excluding the civil servants and apprentices. The study was conducted in Germany. The 
instrument used is a survey. Findings showed that the employees were more productive when they worked at home. Similar findings for positive benefits was also done by Church (2015). The instrument is an online survey. 84 respondents participated in the study. Findings revealed that the employees felt they were more productive working from home. They also said they had improved job satisfaction. Employers also had positive reactions. They felt that employers saved money. They felt that promotional opportunities remained strong. Employers felt that their employees were able to maintain work-life balance as they were highly motivated to work.

Raisiene, Rapuano, Varkuleviciute, and Stachova (2020) investigated how teleworkers evaluated their work. 336 teleworkers responded to a questionnaire. Correlation analysis of the variables showed that there are differences in the evaluation of factors affecting telework efficiency and qualities from a remote worker. These factors differ across gender, ager, education, work experience and experience of working from home. Findings showed that the workers that are most satisfied with teleworking- are millennia woman who have a degree and has 4-10 years professional experience. The most dissatisfied-workers are man of baby boomers with university degree, and had 20 or more years of professional experience.

\section{Conceptual Framework of the Study}

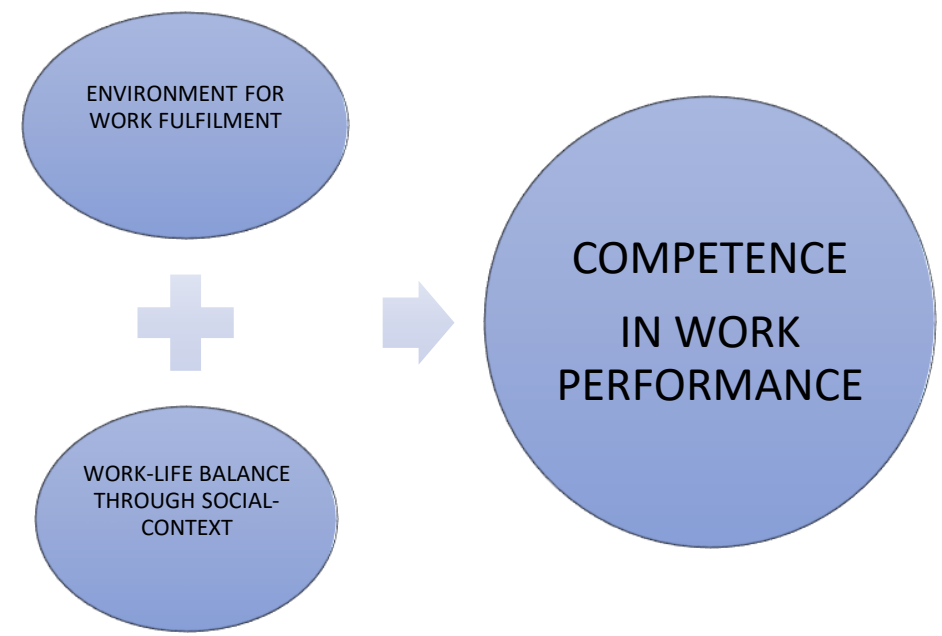

Figure 1- Conceptual Framework of the Study (source: Deci and Ryan, 2000; Abdullah et al., 2020)

The conceptual framework of this study (figure 1) is scaffolded from Deci and Ryan's (2000) cognitive evaluation theory that emphasizes on the environment and social contest to give workers the feeling of competence. The variable of environment is filled by factors that lead to work fulfilment by Abdullah, Rahmat, Zawawi, Khamsah and Anuarsham (2020) . The variable social-context refers to the workers drive to get work-life balance (Abdullah, Rahmat, Zawawi, Khamsah and Anuarsham,2020). Finally when workers feel competent, their work performance increase.

\section{Methodology}

This quantitative pilot study is done to investigate how worker perceived working from home. 44 participants responded to the instrument (survey) The instrument is adapted from the survey by Abdullah, Rahmat, Zawawi, Khamsah and Anuarsham (2020) In ensuring the 
reliability of the instrument, the reliability analysis has been conducted on the instrument comprising of 34 items with four sections; Section A: Demographic Data, Section B: Work Fulfilment, Section C: Work-life Balance and Section D: Work Performance.

Table 1- Reliability statistic for the Instrument

Cronbach Alpha for the whole instrument

\begin{tabular}{l}
$\begin{array}{l}\text { Reliability Statistics } \\
\text { Cronbach's Alpha N of Items }\end{array}$ \\
\hline .919 \\
\hline
\end{tabular}

Table1 above shows the reliability statistics of the instrument. The value of Cronbach's alpha showed the questionnaire to reach acceptable reliability, $\alpha=0.919$.

Table 2: Cronbach Alpha for Section B, C and D

\begin{tabular}{|l|l|l|}
\hline Section & $\begin{array}{l}\text { No. of } \\
\text { Questions }\end{array}$ & $\begin{array}{l}\text { Value of } \\
\text { Cronbach's } \\
\text { Alpha }\end{array}$ \\
\hline Section B - Environment through Work Fulfilment & 10 & .846 \\
Section C - Work-life Balance through Social Context & 10 & .913 \\
Section D - Competence in Work Performance & 10 & .859 \\
\hline
\end{tabular}

Table 2 shows the reliability statistics on Section A, B and C. The value of Cronbach's alpha showed that every section has reached acceptable reliability $\alpha \leq 0.70$ which indicates good internal consistency.

Data is analysed based on the frequency of responses and presented in the form of percentages for the demographic profile and mean score for the variables.

\section{Findings}

Introduction

This section discusses the findings by answering the research questions presented above.

Findings for Demographic Profile

This section describes the demographic data of respondents of study in terms of gender, age, academic achievement, and industry.

Table 3: Gender

\begin{tabular}{|l|l|l|}
\hline & Frequency & Percent \\
\hline Male & 21 & 48 \\
\hline Female & 23 & 52 \\
\hline Total & 44 & 100 \\
\hline
\end{tabular}

Table 3 illustrates the distribution of the students according to their gender. 21 of them $(48.2 \%)$ are male, while another $23(52 \%)$ are female. 
Table 4 Distribution of Respondents according to Age Range

\begin{tabular}{|l|l|l|}
\hline Range of Age & Frequency & Percent \\
\hline $20-29$ years old & 7 & 15.9 \\
\hline $30-39$ years old & 27 & 61.4 \\
\hline $40-49$ years old & 4 & 9.1 \\
\hline $50-59$ years old & 6 & 13.6 \\
\hline Total & 44 & 100 \\
\hline
\end{tabular}

Table 4 depicts the distribution of the respondents according to age range. Seven of them $(15.9 \%)$ were in the age range of $20-29$ years old, 27 of them (61.4\%) were in the range 30 39 years old, four respondents (9.1\%) were in $40-49$ age of range and six of them (13.6\%) were in $50-59$ years old range of age.

Table 5: Distribution of respondents according to Academic Achievement

\begin{tabular}{|l|l|l|}
\hline Academic Achievement & Frequency & Percent \\
\hline Diploma & 2 & 4.5 \\
\hline Degree & 29 & 65.9 \\
\hline Master & 9 & 20.5 \\
\hline PhD & 4 & 9.1 \\
\hline Total & 44 & 100 \\
\hline
\end{tabular}

Table 5 shows the distribution of respondents according to academic achievement. Majority of the respondents were degree holder $(n=29,65.9 \%)$ followed with master holder $(n=9$, $20.5 \%)$, PhD holder $(n=9.1 \%)$ and diploma holder $(n=2,4.5 \%)$

Table 6 Distribution of Respondents according to Industry

\begin{tabular}{|l|l|l|}
\hline Industry & Frequency & Percent \\
\hline Manufacturing & 1 & 2.3 \\
\hline Transportation & 1 & 2.3 \\
\hline Retail Trade & 2 & 4.5 \\
\hline Finance, Insurance and Real Estate & 1 & 2.3 \\
\hline Public Service and Administration & 4 & 9.1 \\
\hline Health Service & 8 & 18.2 \\
\hline Information Technology & 3 & 6.8 \\
\hline Education & 10 & 22.7 \\
\hline Pharmaceutical & 10 & 22.7 \\
\hline Logistics & 1 & 2.3 \\
\hline Others & 3 & 6.8 \\
\hline Total & 44 & 100.0 \\
\hline
\end{tabular}

Table 6 shows the distribution of respondents according to industry. Majority of the respondents were in education and pharmaceutical industries $(n=10,22.7 \%)$ followed with health service industry $(n=8,18.2 \%)$, public service and administration industry $(n=4,9.1 \%)$, retail trade $(n=2,4.5 \%)$, manufacturing, transportation, logistics, and finance, insurance and real estate industries $(n=1,2.3 \%)$ and other industries $(n=3,6.8 \%)$

Findings for Environment for Work Fulfilment 


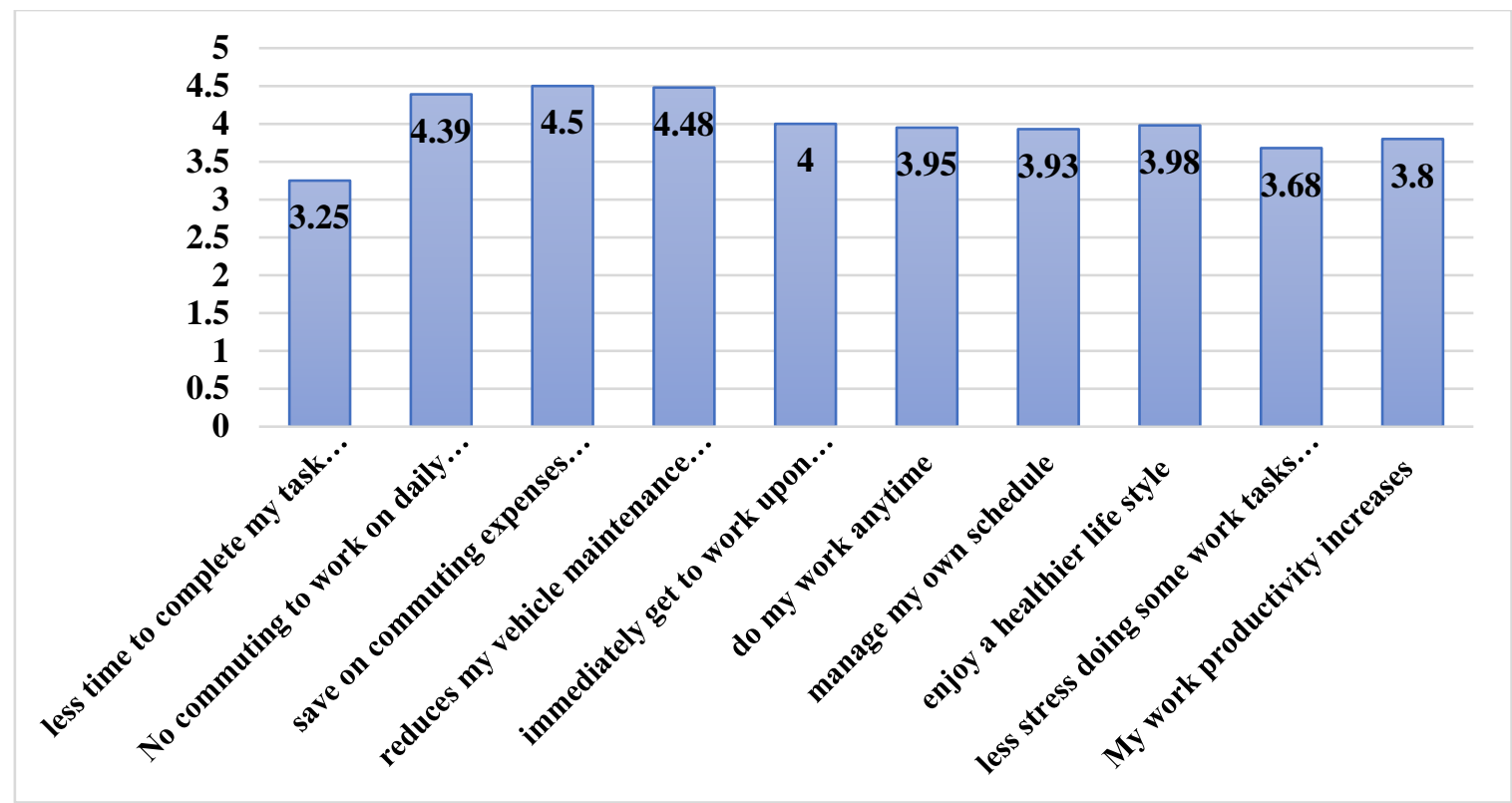

Figure 2-Mean for Environment for Work Fulfilment

Figure 2 shows the mean scores for every item in Section B: Work Environment for Work Fulfilment. The highest mean recorded is on item 7: Money is saved as no commuting expenses required $(M=4.50)$ followed by item 8: Money is saved as it reduces vehicle maintenance cost $(M=4.48)$. While the least mean recorded is on item 5 : Less time needed in completing tasks while working from home $(M=3.25)$.

Findings for Work-Life Balance through Social Context

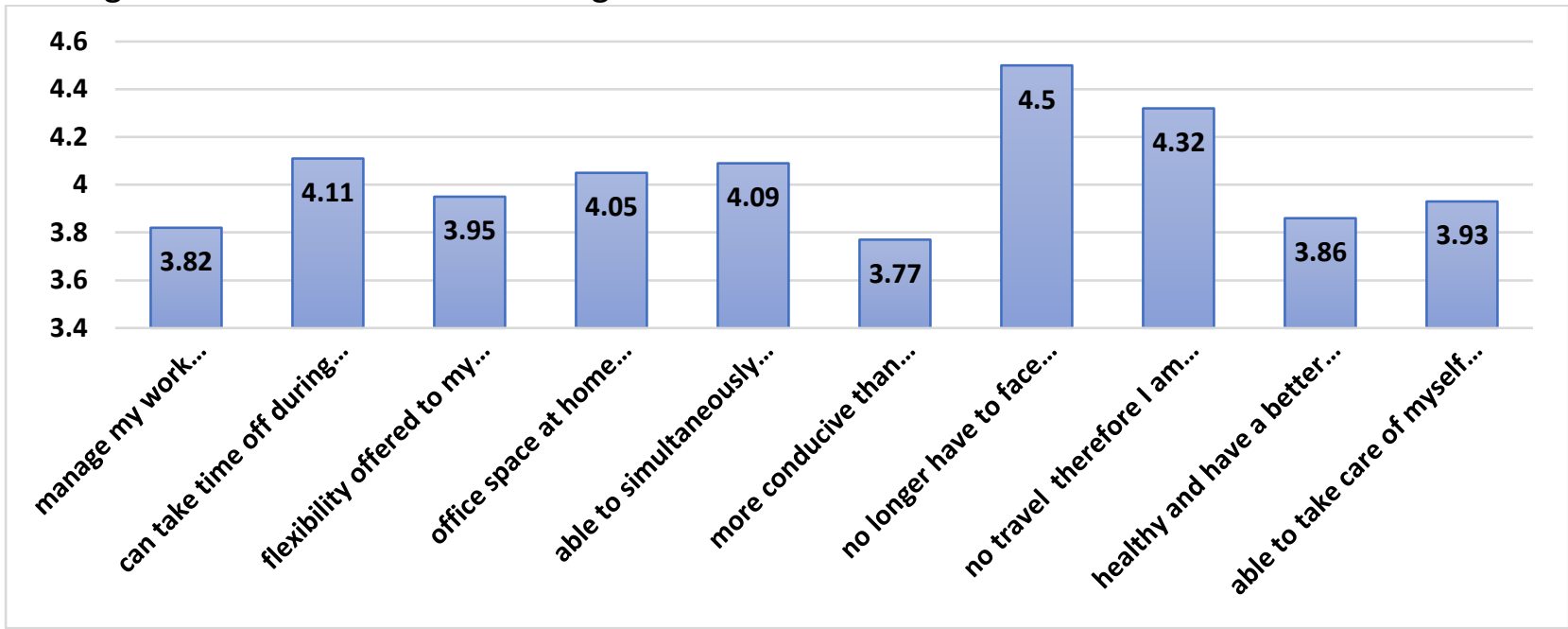

Figure 3- Mean for Work-Life Balance through Social Context

Figure .2 shows the mean scores for every item in Section $C$ : Work-life Balance. The highest mean score obtained is on item 21: Traffic issues is no longer an issue ( $M=4.50)$. The second highest mean is on item 22: More time is available to work on the tasks since no travelling required $(M=4.32)$. The lowest mean is recorded on item 20: Working environment is more conducive than working in an office ( $M=3.77)$.

Findings for Competence in Work Performance 


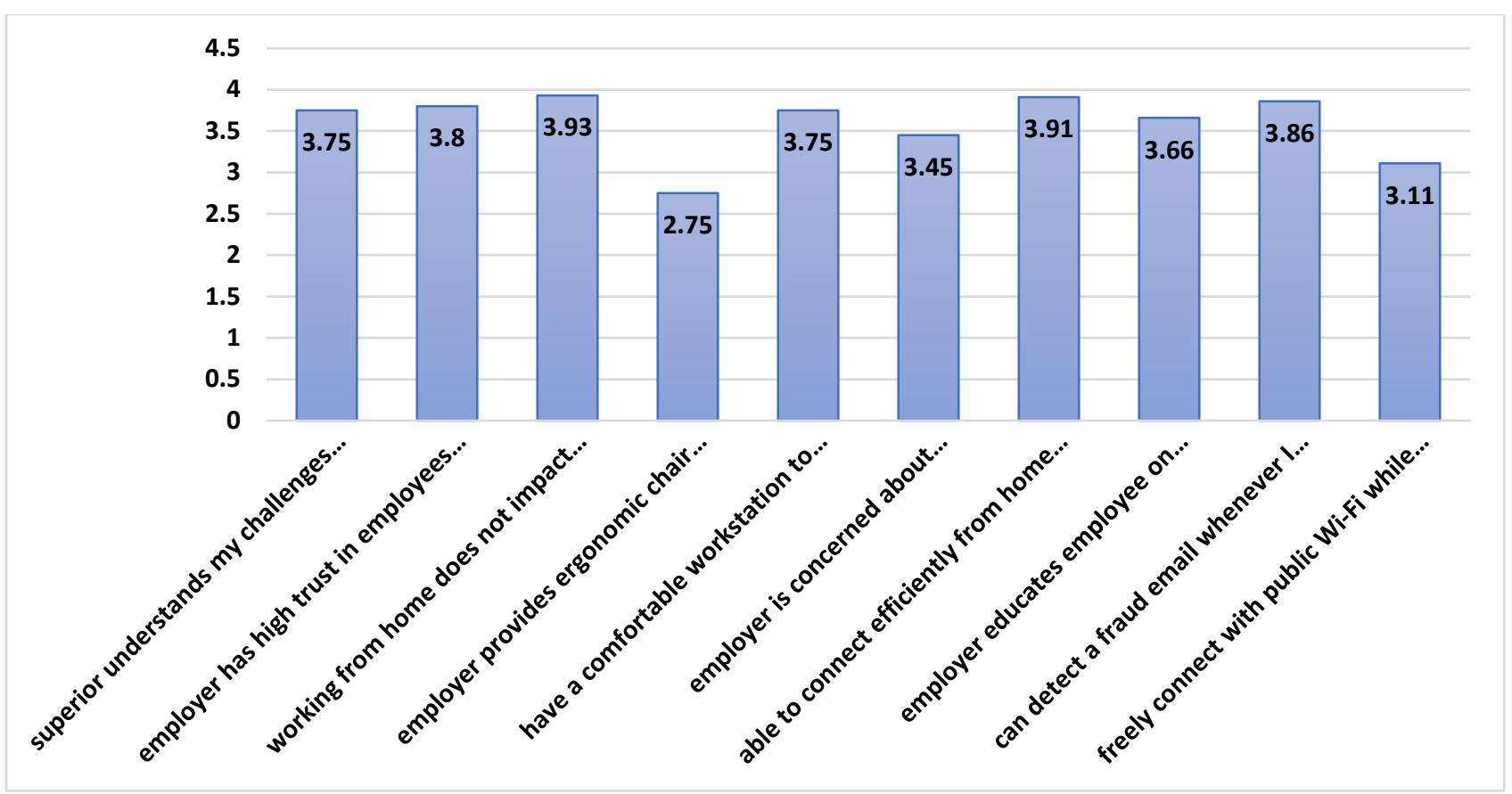

Figure 4-Mean for Competence in Work Performance

Figure 4 shows the mean scores for item in Section D: Competence in Work Performance. The highest mean score obtained is on item 27: Career progression is not affected in any way while working from home $(M=3.93)$. The second highest mean obtained is on item 31: Connecting to internet is easy as I have my own broadband connection ( $M=3.91)$. The lowest mean score recorded is on item 28: Ergonomic chair is prepared by the employer $(M=2.75)$.

Average means obtained for Section B, C, and D

Table 7: Average mean score for Section B, C, and D

\begin{tabular}{|l|l|l|}
\hline Section & Average Mean Score & Indicator \\
\hline Section B : Work Fulfilment & 4.0 & Almost \\
\hline Section C: Work-life Balance & 4.04 & Almost \\
\hline Section D: Work Performance & 3.60 & Almost \\
\hline
\end{tabular}

Table 7 shows the average score of Section B, C and D. The average mean obtained for Section $B$ : Work-fulfilment is 4.00 which indicates that the respondents almost achieve the work fulfilment while working from home. Meanwhile, the average mean for Section B: Work-life Balance is 4.04 which indicates that the respondents almost achieve the work-life balance while working from home. The average mean for the last section, Section D: Work Performance is 3.60 which indicates that the respondents almost achieve good work performance while working from home.

\section{Conclusion}

Summary of Findings and Discussion In summary, this study has shown that work from home has positive impacts on employees' (a) work fulfilment, (b) work-life balance of employees, (c) work performance of employees. 
(a) Work Fulfilment

After extracting all information from the surveys, it is found that the respondents were relatively more productive and agreed that working from home is more conducive compared to the conventional way of working.. The respondents believed that working remotely from home helped them to save money as it reduced the vehicle maintenance As no commuting is needed, the sample said they were able to get more work done as time is saved on travelling purpose. According to CIPD (2016) flexible working has been introduced into organisations as a way for employees and employers to have flexibility within their job roles therefore allowing them to suit their personal needs. This is correlated to the finding of this study as the respondents said work can be done at anytime when they worked remotely. Recent studies have reinforced the notion that working from home does not only increase productivity but also decrease stress (Bhui et.al., 2016). This created an optimal working condition for the respondents hence enhancing their productivity in the long run.

(b) Work Life Balance

Respondents almost achieved work -life balance while working remotely from home. Most of them were happy for being able to take their time off during workdays without loss of pay. This helps the sample to broader their quality of life as they can keep the harmony between their home life and expert life. It is evident to see from this research that all participants believed their performance would not be affected negatively when they were working from home. This links in nicely with the study by Timsal and Awais (2016) that employers are more attracted to organisations that have flexibility of working from the comfort of their homes. This factor impacted the employees' performance levels positively.

\section{(c) Work Performance}

Respondents in this study showed ability to achieve good work performance even though they are not stationed at their conventional workplace. The participants were certain that this new norm did not affect and hinder their work progression adversely. This is supported by a study by Susilo (2020) which revealed that employees experienced greater enjoyment and satisfaction thus enhancing their job performance while working remotely from home. The prominent factor that helped the respondents not to be affected by the fact that they were not actually at their own work station is the ability for them to manage their private affairs during working hours therefore enabling them to seek higher fulfilment of personal life (Shockley \& Allen, 2012). Thus, it is evident from this study that work from home has a significant effect on the respondents' work motivation.

The overall findings of this research suggest that working from home has statistically positive impact on the respondents' work-life balance. It is an imperative factor that helps the participants to perform maximally at their work tasks. The ability for them to deal with their personal and professional affairs concurrently helps them accomplish their tasks and expanse their happiness index. In short, employee work-life balance is essential for sustained development of both the individuals and the organisation.

Implications

Based on this research, it is imperative to highlight that the findings from current study added to the literature on remote work and work-family conflict as it explains why working remotely decreases work-family conflict. The autonomy role given to the employers aid them to be 
responsible for every decision making related to both work and family. In addition, working from home which is experienced by the respondents is perceived as a symbol of gratitude and trust which is given by their employers. Even though they need to pay attention to their personal affairs which are related to their family during their working hours, this does not impede their working performance instead boosting their work morale to do even better at their job. This suggests that working from home should be an option for post covid-19 pandemic. Employers need to extend the trust given to the employees for it benefits both parties in the long run as it aids the organizations in achieving their goals and objectives. The good environment at homes increases the respondents' job satisfaction as they can maintain their presence in a work environment with a peace of mind. This links to many previous studies which suggest that good work performance can be achieved by improving the psychological, social and physical elements of a work environment (Agbozo et al., 2017).

\section{Suggestion for Future Research}

This research has a limited scope as Malaysia is the only country involved in this study due to the authors' limited resources. Further studies could widen the scope of research by collecting data from other countries because working from home policy does not only apply to Malaysia but world-wide. As this study only focuses on the employees' perception, it is interesting to see if the employers have the same insight on the work-from-home policy. Future research may want to consider examining the employers' perception and cross-check with the employees to see if there are any correlations in the findings. Lastly it is suggested for future research to add different types of personalities in relation to remote work and work-life balance for certain personalities may prefer to integrate work with their homes and vice versa ( Schall, 2019). All these could contribute to the body of knowledge and literature related to work-family conflict.

\section{References}

Abdullah, N. A. A., Rahmat, N. H., Zawawi, F. Z., Khamsah, M. A. N., and Anuarsham, A. H. (2020) Coping with Post COVID-19: Can Work from Home ne a New Norm? European Journal of Social Science Studies, Vol 5(6), pp 61-81. Retrieved from https://oapub.org/soc/index.php/EJSSS/article/view/933

Agbozo, G. K., Owusu, I. S., Hoedoafia, M. A., \& Atakorah, Y. B. (2017). The effect of work environment on job satisfaction: Evidence from the banking sector in Ghana. Journal of Human Resource Management, 5(1), 12. Retrieved from http://doi.org./ 10.11648/j.jhrm.20170501.1

Bhui, K. S., Dinos, S., Stansfeld, S. A., White, P. D. (2016). A synthesis of the evidence for managing stress at work: a review of the reviews reporting on anxiety, depression, and absenteeism. J Environ Public Health 2012: pp. 1-13. Retrieved from https://pubmed.ncbi.nIm.nih.gov/22496705/

CIPD. (2016) Change Management [Online] Retrieved from https://www.cipd.co.uk/knowledge/strategy/change/management-factsheet\#8088

Church, N. F. (2015) Gauging Perceived Benefits from "Working from Home" as a Job Benefit. International Journal of Business and Economic Development, Vol 1(3), pp 8189. Retrieved from https://www.ijbed.org/cdn/article_file/content_80934_18-02-2511-43-47.pdf

FastLane. (2020). "Infographic: Work From Home Hong Kong Survey COVID-19." Accessed 17 April 2021. https://fastlanepro.hk/work-from-home-hong-kong-infographic/ 
Gajendran, R. S., and Harrison, D. A. (2007). "The Good, the Bad, and the Unknown About Telecommuting: Meta-Analysis of Psychological Mediators and Individual Consequences." The Journal of Applied Psychology 92 (6): 1524-1541. http://doi.org/10.1037/0021-9010.92.6.1524.

Ryan, R., \& Deci, E. (2000). Self-determination theory and the facilitation of intrinsic motivation, social development, and well-being. American Psychologist, 55(1), 6 8.Retrieved from http://doi.org/ https://doi.org/10.1037//0003-066x.55.1.68

Mello, J. A. (2007). "Managing Telework Programs Effectively." Employee Responsibilities and Rights Journal 19 (4): 247-261. Retrieved from http://10.1007/s10672-007-9051-1.

Purwanto, A., Asbari, M., Fahlevi, M., Mufid, A., Agistiawati, E., Cahyono, Y., and Suryani, P. (2020) Impact of Work from Home (WFH) on Indonesian Teachers' Performance during the COVID19 Pandemic: An Exploratory Study. International Journal of Advanced Science and Technology, Vol 29 (5): pp6235-6244. Retrieved from http://sersc.org/journals/index.php/IJAST/issue/view/272

Raisiene, A. G., Rapuano, V., Varkuleviciute, K., and Stachova, K. (2020) Working from HomeWho is Happy?? A Survey of Lithuania's Employees during the COVIID-19 Quarantine Period. Sustainability, Vol 12(5332), pp 1-21. Retrieved from http://doi.org/ $10.3390 /$ su12135332

Rupietta, K., Beckmann, M. (2016). Working from home: What is the effect on employees' effort?, WWZ Working Paper, No. 2016/07, University of Basel, Center of Business and Economics (WWZ), Basel . Retrieved from https://www.econstor.eu/bitstream/10419/162183/1/889498229.pdf

Schall, M. A. (2019). The Relationship Between Remote Work and Job Satisfaction:

The Mediating Roles of $\mathrm{P}$ The Mediating Roles of Perceived Autonomy, Work-Family Conflict, and Telecommuting Intensity. Retrieved from https://scholarworks.sjsu.edu/cgi/viewcontent.cgi?article=8564\&context=etd_theses

Shockley, K. M., \& Allen, T. D. (2012). Motives for flexible work arrangement use. Community, Work \& Family, 15(2), 217-231. Retrieved from https://www.tandfonline.com/doi/abs/10.1080/13668803.2011.609661

Suresh, G. (2020). Workspace and postural challenges in Work from Home (WFH) Scenario.International Journal of Grid and Distributed Computing, 13(2), 12-20. Retrieved April 14, 2021 Retrieved from from https://www.researchgate.net/publication/344087677_Workspace_and_postural_cha llenges_in_Work_from_Home_WFH_Scenario

Susilo, D. (2020). Revealing the Effect of Work-From-Home on Job Performance during the Covid-19 Crisis: Empirical Evidence from Indonesia. Journal of Contemporary Issues in Business and Government 26(1):23-40. Retrieved from https://cibg.org.au/article_1202.html

Timsal, A., and Awais, M. (2016) 'Flexibility or ethical dilemma: an overview of the work from home policies in modern organisations around the world'. Human Resource Management International Digest, 24(7): pp.12-15. Retrieved from https://eprints.lancs.ac.uk/id/eprint/83014/1/Accepted_Manuscript.pdf

Tumin, S. (2020). Covid-19 and Work in Malaysia: How Common is

Working from Home? [Web log post]. Retrieved April 17, 2021, from https://blogs.Ise.ac.uk/seac/2020/11/23/covid-19-and-work-in-malaysiahow-common-is-working-from-home/

Vyas, L., \& Butakhieo, N. (2020). The impact of working from home during COVID-19 
on work and life domains: An exploratory study on Hong Kong. Policy Design and Practice, 4(1), 59-76. doi:https://doi.org/10.1080/25741292.2020.1863560

Xiao, Y., Becerik-Gerber, B., Lucas, G., and Roll, S. C. (2021) Impacts of Working From Home During COVID-19 Pandemic on Physical and Mental Well-Being of Office Workstation Users, Journal of Occupational and Environmental Medicine: Vol 63 (3), pp 181-190. Retrieved from https://pubmed.ncbi.nlm.nih.gov/33234875/ 